\title{
Development of thirty-four new microsatellite loci and multiplexing of seven existing loci for Zootoca vivipara (Squamata: Lacertidae)
}

\author{
Jose Luis Horreo, ${ }^{1,2}$ Maria Luisa Peláez,,${ }^{3,4}$ Teresa Suárez, ${ }^{4}$ Benoit Heulin, ${ }^{5}$ and Patrick Stefan \\ Fitze $^{1,3}$ \\ ${ }^{1}$ Department of Ecology and Evolution (DEE), University of Lausanne, 1015 Lausanne, Switzerland. E-mail: horreojose@ \\ gmail.com, psfitze@gmail.com. \\ ${ }^{2}$ Department of Biodiversity and Ecologic Restoration, Instituto Pirenaico de Ecología (IPE-CSIC), Avenida Nuestra Señora \\ de la Victoria 16, 22700 Jaca, Spain. \\ ${ }^{3}$ Department of Biodiversity and Evolutionary Biology, Museo Nacional de Ciencias Naturales (MNCN-CSIC), José Gutiérrez \\ Abascal 2, 28006 Madrid, Spain. \\ ${ }^{4}$ Department of Cellular and Molecular Physiopathology, Centro de Investigaciones Biologicas (CSIC), Calle Ramiro de \\ Maetzu 9, E-28040 Madrid, Spain. E-mails: maaller@yahoo.es, teresa@cib.csic.es. \\ ${ }^{5}$ Station Biologique, CNRS UMR 6553, Paimpont 35380, France. E-mail: benoit.heulin@univ-rennes1.fr.
}

\begin{abstract}
Development of thirty-four new microsatellite loci and multiplexing of seven existing loci for Zootoca vivipara (Squamata: Lacertidae). Few microsatellite loci exist for the European common lizard, Zootoca vivipara, a common model species in studies of population dynamics, sexual selection, population genetics, parity evolution, and physiology. The existing primers did not amplify in all lineages, and multiplexes were not optimized. A total of 34 new polymorphic microsatellite markers have been developed for this species and tested in 64 specimens belonging to oviparous and viviparous clades (B and D). The microsatellites were combined into seven different multiplexes. Results showed that all but one loci successfully amplified in all samples and both clades. The number of alleles detected per locus ranged 7-22 alleles and the effective number 1.587.82. The observed heterozygosity ranged $0.312-0.930$, showing that all loci were highly variable. Oviparous and viviparous clades exhibited significant genetic differences (in $\mathrm{F}_{\mathrm{ST}}$ ). In addition to these new markers, the seven previously published and widely used microsatellite loci have been multiplexed and tested in oviparous clades. These innovations will allow for timesaving and robust analyses in Zootoca vivipara, boosting evolutionary and population studies and easing paternity analyses.
\end{abstract}

Keywords: European Common Lizard, Lacerta vivipara, multiplex, NGS, nuclear DNA, viviparity, oviparity.

Received 1 August 2016

Accepted 7 November 2016

Distributed June 2017 


\begin{abstract}
Resumo
Desenvolvimento de trinta e quatro novos locos de microssatélites e otimização de PCR multiplex de sete locos existentes para Zootoca vivipara (Squamata: Lacertidae). Existem poucos locos de microssatélites para o lagarto-comum-europeu, Zootoca vivipara, uma espéciemodelo comum em estudos de dinâmica de populações, seleção sexual, genética de populações, evolução do modo reprodutivo e fisiologia. Os oligonucleotídeos existentes não amplificaram em todas as linhagens, e a reação em cadeia da polimerase (PCR) multiplex não foi otimizada. Um total de 34 novos marcadores polimórficos de microssatélite foi desenvolvido para essa espécie e testado em 64 espécimes dos clados ovíparo e vivíparo (B e D). Os microssatélites foram combinados em sete diferentes agrupamentos. Os resultados mostraram que todos os locos, com uma única exceção, amplificaram com sucesso em todas as amostras e em ambos os clados. O número de alelos detectado por loco variou entre 7 e 22 e o número efetivo, entre 1,58 e 7,82. A heterozigosidade observada variou de 0,312 a 0,930 , mostrando que todos os locos foram altamente variáveis. Os clados ovíparo e vivíparo exibiram diferenças genéticas significativas $\left(\mathrm{em}_{\mathrm{ST}}\right.$ ). Além desses novos marcadores, os sete locos de microssatélite previamente publicados e largamente utilizados foram otimizados em PCR multiplex e testados em clados ovíparos. Essas inovações permitirão análises rápidas e robustas em Zootoca vivipara, impulsionando estudos evolutivos e populacionais e facilitando análises de paternidade.
\end{abstract}

Palavras-chave: DNA nuclear, Lacerta vivipara, lagarto-comum-europeu, PCR multiplex, NGS, oviparidade, viviparidade.

\section{Introduction}

The European Common Lizard, Zootoca vivipara (Lichtenstein, 1823), is the most widely distributed reptile species of the world (Guillaume et al. 2006). Its distribution ranges from Ireland and western Spain in the west to Japan (Hokaido) in the east, and from the Balkans and Pyrenees in the south to the polar circle in the north; there are several clearly distinct lineages across Eurasia (Clades A-F; Surget-Groba et al. 2006). One of these clades has been proposed to be a new species (Clade A; Cornetti et al. 2015a). The species is reproductively bimodal; two lineages are oviparous (Clades A, B) and all the other clades are viviparous (Clades $\mathrm{C}-\mathrm{F}$ ). Owing to the range and reproductive bimodality, $Z$. vivipara is a highly interesting species in terms of its evolution, geography, and population dynamics. Evolutionary studies (e.g., Surget-Groba et al. 2006, Cornetti et al. 2015b) and studies analyzing individual paternities (e.g., Laloi et al. 2004, Fitze et al. 2005, 2008, Richard et al. 2005, 2009, Eizaguirre et al. 2007, Fitze and Le
Galliard 2008, Le Galiard et al. 2008, San-Jose et al. 2014, Breedveld and Fitze 2016) have been conducted on this species, whereas population genetic studies are rather rare. Such studies need reliable, time- and cost-efficient genetic tools; however, few microsatellite loci had been developed, protocols did not work in all lineages (Boudjemadi et al. 1999, Remon et al. 2008, Molecular Ecology Resources Primer Development Consortium 2011), and multiplexes were not optimized (Laloi et al. 2004). Efficient multiplexing (co-amplification of several loci in a single PCR) can significantly decrease the cost of genotyping and increase throughput of microsatellite loci (Guichoux et al. 2011).

We have used next generation sequencing methods to develop a large new panel of microsatellite loci and generated cost-effective multiplexes for new and existing microsatellite loci.

\section{Materials and Methods}

For the development of new microsatellite loci, a total of 64 Zootoca vivipara individuals (Table 1) were sampled. Thirty individuals 
belonged to Clade D (the Eastern Viviparous Clade) and another 34 belonged to Clade B (the Western Oviparous Clade; Surget-Groba et al. 2001). Their genomic DNA was extracted from ethanol-preserved lizard tissue using DNeasy Blood \& Tissue Kit (Qiagen, Verlo, Netherlands), which produces DNA of better quality than other methods (Horreo et al. 2015).

The genomic DNA of one specimen of the Western Oviparous Clade was enriched following the protocol of Santana et al. (2009). A 454 library was obtained from a partial run using the 454 Life Sciences/Roche GS-FLX genome sequence system (Roche Applied Science) (Margulies et al. 2005). A total of 709,643 sequence reads $(153,531,887$ base pairs) was generated, of which 38,000 contained a minimum of five tandem repeats: 17,297 dinucleotides; 16,432 trinucleotides; 3,750 tetranucleotides; 337 pentanucleotides; and 184 hexanucleotides. Ninety-eight of these sequences $(24,58$, and 16 tri-, tetra-, and penta-nucleotides, respectively) were selected to design primers using PRIMER3 (Rozen and Skaletsky 2000). Selected repeats were amplified in eight specimens belonging to all clades described (one individual per lineage: A from Italy, B1 from Spain, B2 from France, $\mathrm{C}$ and $\mathrm{E}$ from Austria, D from Romania, F from Hungary, and $G$ from Galicia Spain) (Surget-Groba et al. 2001, Milá et al. 2013), using 10-100 ng of DNA in a total reaction volume of $10 \mu \mathrm{L}$ and the Taq DNA Polymerase (5PRIME GmbH, Germany). The proportions of the primers, Taq, 5Prime mastermix, magnesium, and molecular-biology grade-water followed the manufacturer's protocol. The PCR started with an initial denaturation step at $95^{\circ} \mathrm{C}$ for $5 \mathrm{~min}$, followed by 35 cycles of denaturation at $95^{\circ} \mathrm{C}$ for $20 \mathrm{~s}$, annealing at $57^{\circ} \mathrm{C}$ for $20 \mathrm{~s}$, extension at $70^{\circ} \mathrm{C}$ for $30 \mathrm{~s}$, and a final extension of $72 \mathrm{vC}$ for $10 \mathrm{~min}$. PCR products were visualized in $2 \%$ agarose gels. If the amplification was successful in all eight specimens, the Forward primer was labelled with a fluorescent-dye (VIC, NED, PET and FAM). Thereafter, successful loci were amplified in a subset consisting of 16 samples of the 64 studied individuals (B and D; Table 1). PCR conditions corresponded to those described above and the total reaction volume was $25 \mu \mathrm{L}$. PCR products were visualized using an automatic sequencer (an ABI 3100, Applied Biosystem) and the software GeneMapper 4.0 (Applied Biosystems). Thirty-four loci (6, 19 and 9 tri-, tetra-, and penta-nucleotides, respectively; Table 2) were polymorphic and exhibited consistently good electropherograms.

The 34 microsatellite loci were combined in seven multiplexes (Table 2), and their amplification followed the "QUIAGEN Type-it Microsatellite PCR Kit" protocol and an annealing temperature of $57^{\circ} \mathrm{C}$. In these multiplexes, 31 primers were employed using the manufacturer's protocol and the proportions of ZV12 (Multiplex 3), ZV29 (Multiplex 6), and ZV32 (Multiplex 7) were 1.5 times higher than those of the other primers. Multiplexes were then amplified in the 64 samples and Tandem v.1.09 (Matschiner and Salzburger 2009) was used for allele binning. Thirty-three loci successfully amplified in all 64 samples. Locus ZV14 amplified in all oviparous samples (Clade B), but it did not amplify in most of the 30 viviparous specimens (Clade D; Table 1) despite its amplification during the development of the method.

Table 1. Sampling details for Zootoca vivipara. The clades have been named according to Surget-Groba et al. (2001). $N=$ sample size. Acronyms: ND = newly developed microsatellites; $\mathrm{EM}=$ existing microsatellites.

\begin{tabular}{lcccc}
\hline Microsatellites & N & Clade & Country & Reproductive mode \\
\hline ND & 30 & D & Hungary/Romania & Viviparous \\
ND & 34 & B & France/Spain & Oviparous \\
EM & 12 & B & Spain & Oviparous \\
\hline
\end{tabular}


Horreo et al.

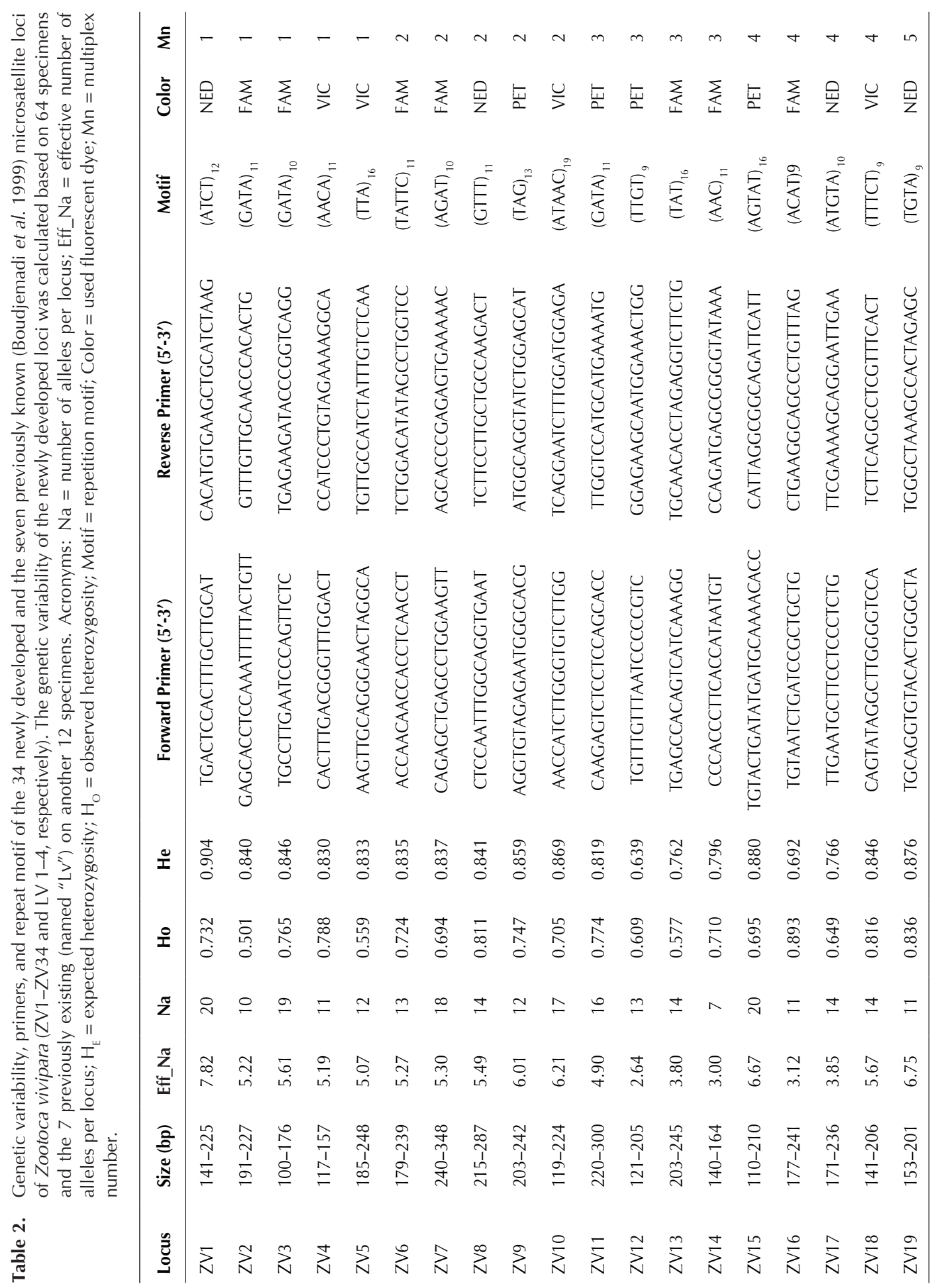


Development of thirty-four new microsatellite loci and multiplexing of seven existing loci for Zootoca vivipara

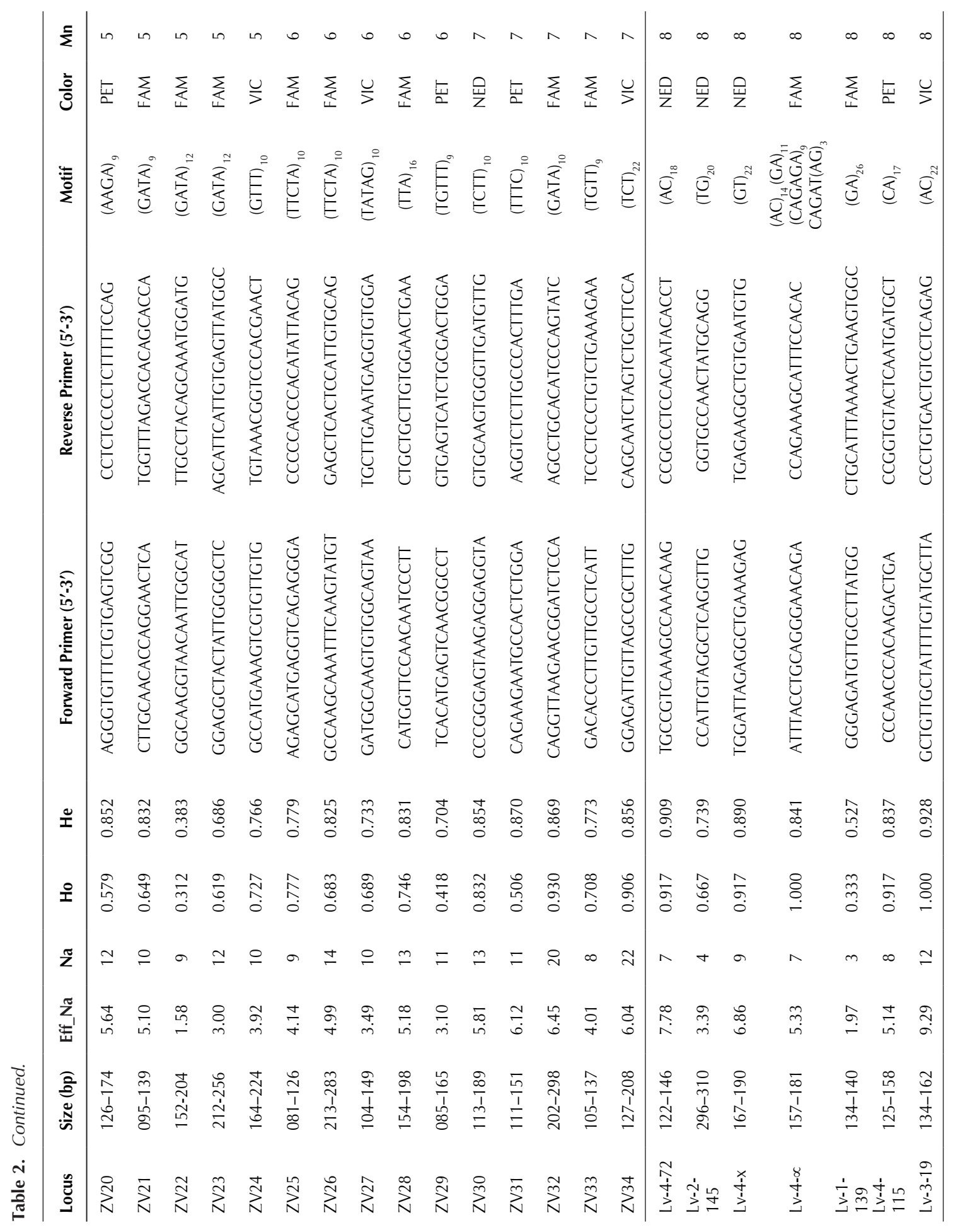


In addition to all this, seven previously published (Lv-3-19, Lv-4-72, Lv-4-alpha, Lv2-145, Lv-4-X, Lv-4-115, Lv-1-139; Table 2) (Boudjemadi et al. 1999) and commonly used microsatellite loci (e.g., Breedveld and Fitze 2016) were multiplexed to save money and time. PCR conditions were the same as those described above, except that annealing was conducted at $58^{\circ} \mathrm{C}$. In the newly developed multiplex, the primers Lv-4-X, Lv-4-alpha, and Lv-3-19 were employed in a proportion three times higher than the rest. A set of 12 oviparous samples was amplified using the multiplex protocol and the previous protocols (following Laloi et al. 2004).

The genetic variability of all the loci (number of alleles per locus, effective number of alleles per locus, and observed and expected heterozygosity), as well as the genetic differentiation among sample groups $\left(\mathrm{F}_{\mathrm{ST}}\right)$ were calculated with GenoDive 2.0b25 (Meirmans and Van Tienderen 2004). The linkage disequilibrium among pairs of loci was calculated with GENEPOP v.4 (Rousset 2008).

\section{Results}

The 34 newly developed loci exhibited high genetic variability (Table 2 ). The mean number of alleles per locus ( \pm standard deviation, obtained through jackknifing) was $13.29 \pm 0.63$; the effective mean number of alleles per locus was $4.89 \pm 0.24$. The mean expected heterozygosity was $0.79 \pm 0.02$ and the mean observed heterozygosity was $0.69 \pm 0.02$. No linkage disequilibrium was detected among pairs of loci. The fixation index $\left(\mathrm{F}_{\mathrm{ST}}\right)$ among clades $(\mathrm{B}$ and $\mathrm{D})$ using 33 loci was significant $\left(p=0.01, \mathrm{~F}_{\mathrm{ST}}=\right.$ 0.082 ), indicating that genetic differences among clades can be detected with the newly developed loci.

In the case of the seven previously published loci, both the multiplex protocol developed here and the previous protocols rendered the exactly same genotypes. The mean number of alleles per locus ( \pm standard deviation) was $7.57 \pm 1.21$; the effective mean number of alleles per locus was $5.68 \pm 0.95$. The mean expected heterozygosity was $0.81 \pm 0.05$ and the mean observed heterozygosity was $0.82 \pm 0.05$. Thus, the range of variability of both the newly developed and the old loci was similar $\left(A_{\mathrm{e}}\right.$ new: $1.58-7.82 ; A_{\mathrm{e}}$ old: 1.97-9.29). ZV22 was the least variable of the new loci and, of the previously published loci, LV-1-139 was the least variable in the oviparous clade, but not in the viviparous Clade E (Boudjemadi et al. 1999).

\section{Discussion}

Thirty-four newly developed, highly polymorphic microsatellite loci (combined in seven different multiplexes) and new multiplexing techniques for seven existing loci (Boudjemadi et al. 1999) described here were tested in viviand oviparous clades of the European Common Lizard, Zootoca vivipara. Thirty-three of the new and all seven old markers amplified in all samples. ZV14 only amplified in the oviparous individuals belonging to Clade $\mathrm{B}$, but not in the viviparous Clade D. Because Clade A is strongly divergent (Cornetti et al. 2015a) in addition to the fact that we tested the amplification of the newly developed microsatellite markers in only one individual belonging to Clade A, it may be interesting to test the effectiveness of the new microsatellite markers in this clade further. Previous to this study, only seven microsatellite loci were available for this species (Boudjemadi et al. 1999, Remon et al. 2008, Molecular Ecology Resources Primer Deveolpment Consortium 2011) and their amplification protocol was not optimized. The loci and protocols we developed provide strong, economical tools for evolutionary and population genetic studies, including the identification of population structure and management/conservation units, the estimation of gene flow, effective population sizes, and for other applications including costefficient paternity analyses. 


\section{Acknowledgments}

Jose L. Horreo was supported by a FICYT Clarín-EU Marie Curie Co-Found (ACA14-26) and a Spanish MINECO postdoc grant FPDI2013-16116. Project funds were provided by the Swiss National Science Foundation (PPOOP3_128375, PP00P3_152929/1 to P. S. Fitze). Benoit Heulin was funded by the French National Research Center (CNRS). The study conducted complies with the current Spanish laws and with ASAB/ABS Guidelines for the Treatment of Animals in Behavioural Research. The authors declare that they have no conflict of interest.

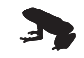

\section{References}

Boudjemadi, K., O. Martin, J. C. Simon, and A. Estoup A. 1999. Development and cross-species comparison of microsatellite markers in two lizard species, Lacerta vivipara and Podarcis muralis. Molecular Ecology 8: $518-520$.

Breedveld, M. C. and P. S. Fitze. 2016. The timing and interval of mate encounter affects investment during mating. Biological Journal of the Linnean Society 118: 613-617.

Cornetti, L., F. Belluardo, S. Ghielmi, G. Giovine, G. F. Ficetola, G. Bertorelle, C. Vernesi, and H. C. Hauffe. 2015a. Reproductive isolation between oviparous and viviparous lineages of the Eurasian common lizard Zootoca vivipara in a contact zone. Biological Journal of the Linnean Society 114: 566-573.

Cornetti, L., G. F. Ficetola, S. Hoban, and C. Vernesi. 2015b. Genetic and ecological data reveal species boundaries between viviparous and oviparous lizard lineages. Heredity 115: 517-526.

Eizaguirre, C., D. Laloi, M. Massot, M. Richard, P. Federicim, and J. Clobert. 2007. Condition dependence of reproductive strategy and the benefits of polyandry in a viviparous lizard. Proceedings of the Royal Society B, Biological Sciences 274: 425-430.

Fitze, P. S., J. F. Le Galliard, P. Federici, M. Richard, and J. Clobert. 2005. Conflict over multiple-partner mating between males and females of the polygynandrous common lizards. Evolution 59: 2451-2459.

Fitze, P. S., J. Cote, J. P. Martínez-Rica, and J. Clobert. 2008. Determinants of male fitness: disentangling intra- and inter-sexual selection. Journal of Evolutionary Biology 21: 246-255.

Fitze, P. S. and J. F. Le Galliard. 2008. Operational sex ratio, sexual conflict and the intensity of sexual selection. Ecology Letters 11: 432-439.

Guichoux, E., L. Lagache, and S. Wagner, P. Chaumeil, P. Léger, O. Lepais, C. Lepoittevin, T. Malausa, E. Revardel, F. Salin, and R. J. Petit. 2011. Current trends in microsatellite genotyping. Molecular Ecology Resources 11: 591-611.

Guillaume, C. P., B. Heulin, I. Y. Pavlinov, D. V. Semenov, A. Bea, N. Vogrin, and Y. Surget-Groba. 2006. Morphological variations in the common lizard, Lacerta (Zootoca) vivipara. Russian Journal of Herpetology 13: $1-10$.

Horreo, J. L., M. L. Peláez, and P. S. Fitze. 2015. Skin sheds as a useful DNA source for lizard conservation. Phyllomedusa 14: 73-77.

Laloi, D., M. Richard, J. Lecomte, M. Massot, and J. Clobert. 2004. Multiple paternity in clutches of common lizard Lacerta vivipara: data from microsatellite markers. Molecular Ecology 13: 719-723.

Le Galiard, J. F., J. Cote, and P. S. Fitze. 2008. Lifetime and intergenerational fitness consequences of harmful male interactions for female lizards. Ecology 89: 56-64.

Margulies, M., M. Egholm, W. E. Altman, S. Attiya, J. S. Bader, L. A. Bemben, J. Berka, M. S. Braverman, Y. J. Chen, Z. Chen, S. B. Dewell, L. Du, J. M. Fierro, X. V. Gomes, B. C. Godwin, W. He, S. Helgesen, C. H. Ho, G. P. Irzyk, S. C. Jando, M. L. I. Alenquer, T. P. Jarvie, K. B. Jirage, J. B. Kim, J. R. Knight, J. R. Lanza, J. H. Leamon, S. M. Lefkowitz, M. Lei, J. Li, K. L. Lohman, H. Lu, V. B. Makhijani, K. E. McDade, M. P. McKenna, E. W. Myers, E. Nickerson, J. R. Nobile, R. Plant, B. P. Puc, M. T. Ronan, G. T. Roth, G. J. Sarkis, J. F. Simons, J. W. Simpson, M. Srinivasan, K. R. Tartaro, A. Tomasz, K. A. Vogt, G. A. Volkmer, S. H. Wang, Y. Wang, M. P. Weiner, P. Yu, R. F. Begley, and J. M. Rothberg. 2005. Genome sequencing in microfabricated highdensity picolitre reactors. Nature 437: 376-380.

Matschiner, M. and W. Salzburger. 2009. TANDEM: integrating automated allele binning into genetics and genomics workflows. Bioinformatics 25: 1982-1983.

Meirmans, P. G. and P. H. Van Tienderen. 2004. GENOTYPE and GENODIVE: two programs for the analysis of genetic diversity of asexual organisms. Molecular Ecology Resources 4: 792-794.

Milá, B., Y. Surget-Groba, B. Heulin, A. Gosá, and P. S. Fitze. 2013. Multilocus phylogeography of the common 
lizard Zootoca vivipara at the Ibero-Pyrenean suture zone reveals lowland barriers and high-elevation introgression. BMC Evolutionary Biology 13: 192.

Molecular Ecology Resources Primer Deveolpment Consortium. 2011. Permanent genetic resources added to Molecular Ecology, Resources Database - 1 December 2010-31 January 2011. Molecular Ecology Resources 11: $586-589$.

Remon, N., M. Vila, P. Galán, and H. Naveira. 2008. Isolation and characterization of polymorphic microsatellite markers in Iberolacerta monticola, and crossspecies amplification in Iberolacerta galani and Zootoca vivipara. Molecular Ecology Resources 8: 1351-1353.

Richard, M., M. Lecomte, M. Fraipont, and J. Clobert. 2005. Age-specific mating strategies and reproductive senescence. Molecular Ecology 14: 3147-3155.

Richard, M., S. Losdat, J. Lecomte, M. Fraipont, and J. Clobert. 2009. Optimal level of inbreeding in the common lizard. Proceedings of the Royal Society B, Biological Sciences 276: 2779-2786.

Rousset, F. 2008. Genepop`007: a complete re-implementation of the Genepop software for Windows and Linux. Molecular Ecology Resources 8: 103-106.

Rozen, S. and H. J. Skaletsky. 2000. Primer3 on the WWW for general users and for biologist programmers. Pp 365386 in S. Miseber and S. A. Krawetz (eds.), Methods in Molecular Biology, Series Bioinformatics Methods and Protocols, Volume 132. Totowa. Humana Press Inc.
San-Jose, L. M., M. Peñalver-Alcázar, B. Milá, V. GonzalezJimena, and P.S. Fitze. 2014. Cumulative frequencydependent selective episodes allow for rapid morph cycles and rock-paper-scissors dynamics in species with overlapping generations. Proceedings of the Royal Society of London, Series B, Biological Sciences 281: 20140976.

Santana, Q. C., M. P. A. Coetzee, E. T. Steenkamp, O. X. Mlonyeni, G. N. A. Hammond, M. J. Wingfield, and B. D. Wingfield. 2009. Microsatellite discovery by deep sequencing of enriched genomic libraries. BioTechniques 46: 217-223.

Surget-Groba, Y., B. Heulin, C. P. Guillaume, R. S. Thorpe, L. Kupriyanova, N. Vogrin, R. Maslak, S. Mazzotti, M. Venczel, I. Ghira, G. Odierna, O. Leontyeva, J. C. Monney, and N. Smith. 2001. Intraspecific phylogeography of Lacerta vivipara and the evolution of viviparity. Molecular Phylogenetics and Evolution 18: $449-459$.

Surget-Groba, Y., B. Heulin, C. P. Guillaume, M. Puky, D. Semenov, V. Orlova, L. Kupriyanova, I. Ghira, and B. Smajda. 2006. Multiple origins of viviparity, or reversal from viviparity to oviparity? The European Common Lizard (Zootoca vivipara, Lacertidae) and the evolution of parity. Biological Journal of the Linnean Society 87: $1-11$.

Editor: Jaime Bertoluci 